DOI: $10.17951 / \mathrm{m} .2016 .1 .173$

\begin{tabular}{lcr}
\hline & ANNALES \\
& UNIVERSITATIS MARIAE CURIE-SKŁODOWSKA \\
VOL. I & LUBLIN - POLONIA & \\
\hline
\end{tabular}

Zoltan J. Toth

Károli Gáspár University, Budapest

\title{
The Methods of Statutory Interpretation in the Practice of the High Courts of Hungary
}

\section{Introduction}

It is a cliché in the jurisprudence that written legal norms perpetually need to be interpreted due to the medium through which the language is able to manifest itself being always vague and ambiguous. Therefore, however much a statute be precisely prepared and drafted, such situations inevitably occur when one cannot decide whether or not a norm in hand concerns a given statement of facts and if they can then what is its 'real' tenor ${ }^{1}$. Exactly for this reason, legal provisions always need to be interpreted before application, that is, that the most adequate meaning has to be revealed relevant to the hermeneutic situation in question.

1 H.L.A. Hart called this immanent ambiguity the 'open texture of law'. According to Hart, a text of a legal norm as a linguistic phenomenon always has a core which encompasses the paradigmatic instances thereof, however, they also have an uncertain halo in the cases of which one cannot undoubtedly define whether or not a provision of a legal norm operating with 'general classifying terms' covers a particular instance. " $[t]$ here is a limit, inherent in the nature of language, to the guidance which general language can provide. [...] 'Canons of interpretation' cannot eliminate, though they can diminish, these uncertanties; for these canons are themselves general rules for the use of language, and make use of general terms which themselves require interpretation. Natural languages [...] irreducibly open-textured. The open texture of law means that there are, indeed, areas of conduct where much must be left to be developed by courts or officials striking a balance, in the light of circumstances, between competing interests which vary in weight from case to case." H.L.A. Hart, The Concept of Law, Clarendon Press, Oxford 1997, pp. 126, 128 and 135. 
There is a social consensus in lots of cases on what a given word, term, idiom, sentence or longer text indisputably means, hence, the present paper does not examine all cognitive reconstruction processes under the subject of the 'methods of statutory interpretation', or, broadly speaking, those of legal interpretation, but only those in the cases of which the law enforcer does reveal the meaning of a really ambiguous and debatable text.

In pursuance of this process, let the present author start out from Jerzy Wróblewski's categories, according to whom the term 'interpretation' can be seen with three levels. In the broadest sense ('largissimo sensu') 'interpretation' concerns any cultural object, including man-made materials, phenomena or thing, "i. e. works of art, written texts and all instruments from a paleolithic axe to a contemporary computer" ${ }^{2}$. In broad sense ('sensu largo') this expression refers only to the comprehension of the terms of spoken or written language as well as any manifestation thereof; finally, in the narrowest sense ('sensu stricto'), one can use the concept of 'interpretation' to define the meaning of a given text if and only if its 'proper' meaning is dubious and one wills to reveal this 'proper' but, at first glance, not unequivocal meaning of the text in question. I will regard 'interpretation' in the present paper as its third, narrowest sense and meaning ${ }^{3}$.

Legal interpretation and, within it, statutory interpretation as an operation is related to the act of argumentation, but is not identical therewith. Legal argumentation covers every act that 'actors in law' do so as to be able to persuade others that a certain standpoint is correct $t^{4}$, while legal interpretation, as a small

2 J. Wróblewski, Legal reasonings in legal interpretation, "Logique et Analyse", 1969, no. 45, p. 4.

3 In this matter I follow the conception of the so-called 'Bielefelder Kreis', a group of contemporary legal scholars who, in the course of the international comparative analysis of the modern statutory intepretation, also perceived the term 'interpretation' in the narrowest sense.

4 At this point, using Pereleman's terms and theory, it is to be differentiated between argumentation and demonstration. The latter one is a logical operation by which one can come to a true conclusion from true premises. On the contrary, the former one is a rhetorical practice during which one, on the basis of plausible but not assuredly true premises, can come to a probable conclusion, aiming the audience to accept the speaker's statement. Therefore, "in argumentation, contrary to what happens in demonstration, we do not justify anything", so the theory of argumentation does no more than to study "the discursive techniques which make it possible to evoke or further people's assent to the theses presented for their acceptance". Ch. Perelman, The Idea of Justice and the Problem of Argument, Routledge \& Kegan Paul, London 1963, p. 157 and 155, respectively. Similarly, "[t]he aim of argumentation is not to deduce consequences from given premises; it is rather to elicit or increase the adherence of the members of an audience to theses that are presented for their consent". Idem, The Realm of Rhetoric, University of Notre Dame Press, Notre Dame, Indiana 1982, p. 9. For a similar distinction between dialectical and analytical reasoning, see: Ibidem, p. 3. 
and special part of legal argumentation ${ }^{5}$, is a process during which a person examining a particular text of the law (that is, in the case of the present article, a statutory text) comes to a conclusion he/she deems proper, that is, during which the interpreter finds out what, at least according to him/her, a given text means. As Niklas Luhmann put it: "while in interpretation one [...] has the mental activity of a single reader in mind, argumentation as an operation is

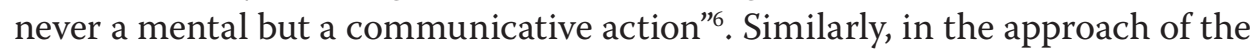
research group 'CERMEG', while statutory interpretation is purely a 'monological' reasoning, argumentation is a 'dialogical' one ${ }^{7}$. Argumentation, however, is pursued not (only) by the decisionmaker in the litigation, that is, the judge, but by the participants therein as well. In what follows, I will only be concerned with statutory interpretation as a cognitive activity by which the interpreter attempts to ascertain what the most adequate meaning of a given statutory text (or a pool of appliable statutory texts) is, concerning, of course, all the possible and defensible meanings of the given text(s), and, in turn, I will neglect the analysis of that judicial (or any parties') activity by which one tries to persuade others that his/her standpoint(s) and/or conclusion(s) is/are right.

\section{A classification of methods of statutory interpretation}

In the topic of the methods of legal hermeneutics one can distinguish two main research subjects. On the one hand, the question of legal theory that being whether some kinds of methods can have the interpretation of legal norms, and, on the other hand, the matter of sociology of law in how often and to which extent

5 As Neil MacCormick formulated it, interpretation "is a particular form of practical argumentation in law, in which one argues for a particular understanding of authoritative texts or materials as a special kind of (justifying) reason for legal decisions". (Cf:: N.D. MacCormick, Argumentation and Interpretation in Law, "Argumentation", July 1995, Vol. 9, Issue 3, pp. 467-480.) For the issue of interpretation as a part of argumentation, see, additionally, e.g.: G.E. Devenish, The Nature of Legal Reasoning Involved in the Interpretation of Statutes, "Stellenbosch Law Review”, 1991, Vol. 2, Issue 2, pp. 224-225; M. Gebauer, Uniform Law, General Principles and Autonomous Interpretation, "Uniform Law Review", 2000, Vol. 5, Issue 4, pp. 68; E.A. Scallen, Classical Rhetoric, Practical Reasoning, and the Law of Evidence, "American University Law Review", June 1995, Vol. 44, Issue 5, pp. 1731, 1734; A.J., Judicial Reasoning in Constitutional Courts: A European Perspective, "German Law Journal", August 2013, Vol. 14, Issue 8, pp. 1219-1220, 1230-1231; M. Van Hoecke, F. Ost, Legal Doctrine in Crisis: Towards a European Legal Science, "Legal Studies", June 1998, Vol. 18, Issue 2, pp. 198.

6 Cf:: N. Luhmann: Legal Argumentation: An Analysis of its Form, “The Modern Law Review", 1995, Vol. 58, no. 3, p. 290.

7 Cf: M. Manzin, A rhetorical approach to legal reasoning: The Italian experience of CERMEG, [in:] Exploring Argumentative Contexts, eds. F.H. van Eemeren, B. Garssen, John Benjamins Publishing Company, Amsterdam 2012, pp. 141-145. 
the organs do of the administration of justice use these methods indeed in their practice. In this study I am going to concentrate on the latter in the above, wishing to examine which technique variations predominate in the course of the interpretation of written legal norms by higher courts, and, chiefly, by the late Supreme Court of Hungary (in its present official name from 1 January 2012: Curia), that is, which methods are used often, sometimes, rarely or never in deciding what a certain legal text means in the context of the factual circumstances at hand ${ }^{8}$.

As the grounds of this empirical legal sociological study, I will employ my own methodological classification which includes altogether 14 main methods and numeruous subtypes therein ${ }^{9}$. Of them, the most trivial is the (1.) grammatical interpretation ${ }^{10}$. It can be either (1/A.) interpretation in accordance with ordinary meaning, and, within it, (1/A.a.) semantic or (1/A.b.) syntactic interpretation $^{11}$; or (1/B.) legal professional (dogmatic) interpretation, and, within it,

8 At present, principally Béla Pokol is the only legal scholar who has pursued a comprehensive research in this topic. As for his results, see: B. Pokol, A felsőbirósági jogértelmezés Magyarországon, "Jogtudományi Közlöny", 1999, no. 1, pp. 493-498. Besides this study, there were some minor analyses, concerning certain branches of law, see e.g.: V. Botos, A birói jogértelmezés útjai a Legfelsóbb Bíróság gyakorlatában, "Jogelméleti Szemle", 2000, no. 3., jesz.ajk.elte.hu; B. Keszthelyi, A büntető jogegységi határozatok elemzése, "Jogelméleti Szemle", 2000, no. 3., jesz.ajk.elte.hu; A. Makai, Â. Parádi, Büntetô jogértelmezés Magyarországon a '90-es években, “Jogelméleti Szemle", 2000, no. 3., jesz.ajk.elte.hu; T. Pohlmüllner, Közigazgatási határozatok 1997-99, "Jogelméleti Szemle", 2000, no. 3., jesz.ajk.elte.hu.

9 Because of the thematic constraints and extensional and rational bounds, this paper cannot review the long historical developement of legal theoretical thinking in the course of which newer and newer techniques appeared in the judicial practice and gained recognition amongst legal theorists. Hence, I only refer to the fact that, certainly, the majority of the methods of my paper's typology came into existence as a result of this development, and, largely, only their labeling was doubtful and controversial at most. Nevertheles, the most important works are as follows: F.C. von Savigny, System des heutigen Römischen Rechts, Erster Band, Berlin 1840; B. Windscheid, Lehrbuch des Pandektenrechts, Erster Band, Verlagshandlung von Julius Buddeus, Düsseldorf 1873; R. von Jhering, Der Zweck im Recht. Erster Band, Druck und Verlag von Breitkopf \& Härtel, Leipzig 1877; P. Heck, Gesetzauslegung und Interessenjurisprudenz, Verlag von Mohr, Tübingen 1914; I. Szabó, A jogszabályok értelmezése, Közgazdasági és Jogi Könyvkiadó 1960; W. Fikentscher, Methoden des Rechts, J.C.B. Mohr, Tübingen 1975-1977.

10 This method is, generally, the starting point. As Atiyah and Summers write, "[w]e can hardly doubt, that there must be principles of statute law enabling us to supplement the literal words in various ways and for various purposes; but, subject to this, the English theory requires the court to try to interpret statutory provisions in accordance with the literal or plain meaning, and without regard to policies or rationales, unless the statute itself is first determined to be unclear." P.S. Atiyah, R.S. Summers, Form and Substance in Anglo-American Law. A Comparative Study of Legal Reasoning, Legal Theory, and Legal Institutions. Clarendon Press, Oxford 1987, p. 102. This statement is true not only for the English but for continental (including Hungarian) legal theory and practice of judiciary as well.

11 In pursuance of semantic interpretation one determines what a single word, phrase, sentence element, sentence or a longer text means on the basis of a general agreement of native 
(1/B.a.) simple conceptual (dogmatic) interpretation, (1/B.b.) interpretation explicitly by principles of statutes or branches of law, (1/B.c.) contextual interpretation in its broad sense ${ }^{12}$ (including the so-called 'derogation formulas ${ }^{13}$ as well); or $(1 / C$.) interpretation in accordance with other (non-legal) professions' terminus technici (technical terms). The 2nd method is the contextual interpretation in its narrow sense $^{14}$, and the 3rd one is the interpretation in accordance with former judgemade law. Judge-made law consists of three kinds, namely court case decisions, sentencing practice and abstract judicial norms. Therefore, it can happen when the sentencing court, in order to ascertain what an ambiguous statutory text means in deed, refers either (3/A.) only to the 'solid and undiminished' judicial practice, or (3/B.) exclusively to former case decisions as 'precedents', or $(3 / C$.) solely to judge-made abstract norms, which are compulsory, officially or nonofficially, for minor courts, or (3/D.) to both sentencing practice and, underlying $i$, concrete precedents, or $(3 / E$.) to both sentencing practice and, corroborating it, judicial abstract norms, or (3/F.) to both judicial abstract norms and, conforming it, concrete case decisions, or, lastly, to (3/G.) sentencing practice, judicial abstract norms and, underlying the former ones, court case decisions, simultaneously.

Besides the techniques in conformity with former judge-made law there are also (4.) interpretation methods in accordance with other (non-judicial) public authorities in the administration of justice. Such can be (4/A.) interpretation as per public authorities' principled decisions, (4/B.) interpretation as per other domestic administrative organs' (e.g. ombudsmen) case decisions and declared opinions and $(4 / C$.) interpretation in conformity with judgements or sentencing practice of international judicial forums under the scope of their authority.

speakers, and in pursuance of syntactic interpretation one reveals, on the grounds of copulatives, what kind of relation exists between single parts of a sentence or single sentences.

12 The expression of 'contextual interpretation' has a narrower and a broader meaning. In its broader sense there are cases belonging to it when a court finds the meaning of a given provision (be that in either an act or a decree) on the score of, that is, in accordance with, in consideration of other specific regulations of either the same statute or other statutes. With regards to its narrower meaning, I will speak about 'contextual interpretation' in cases when one tries to define the meaning of a legal norm by virtue of the designation that derives purely from the emplacement of the provision to be interpreted in the system of the legal norms (that is where one can find that provision, namely, in which statute, part, chapter, subchapter, title, article etc.), without setting it against other statutory provisions.

13 These are the following. 1) Lex superior derogat legi inferiori, that is, the higher norm (in the hierarchy of the formal legal sources) precedes the lower norm. 2) Lex specialis derogat legi generali, that is, the rule made for specific legal relations precedes the rule drafted for general application. ("Generi per speciem derogatur.") 3) Lex posterior derogat legi priori, that is, the latter rule precedes the former rule which results in the prevalence of the most recent legal norm out of several conflicting ones.

14 See note 7 supra. 
The 5th possible method is the logical interpretation ${ }^{15}$, the most common forms of which are (5/A.) argumentum a minori ad maius, (5/B.) argumentum a maiori ad minus, (5/C.) argumentum ad absurdum, (5/D.) argumentum a contrario and (5/E.) argumentum a simili ${ }^{16}$, however, besides these, there can be $\left(5 / F\right.$.) other logic formulas ${ }^{17}$ as well. The 6 th one is the teleological interpretation, based on the objective purpose of the statute enacted, the 7th one, however, is

15 It is highly important to distinguish the so-called fallacies from logical interpretation. As for the former, they may not be applied in statutory interpretation, or even if they may be, they cannot be regarded as logical reasons. Kevin W. Saunders enumerates the sorts of informal fallacies, specifying eighteen ones. According to him, these are the following: 1) argumentum ad hominem; 2) argumentum ad misericordiam; 3) argumentum ad populum; 4) argumentum ad vericundiam; 5) ignoratio elenchi; 6) petitio principii; 7) post hoc ergo propter hoc; 8) argumentum ad ignorantiam; 9) argumentum ad terrorem; 10) argumentum ad antiquitam; 11) accident 12) hasty generalization; 13) composition; 14) division; 15) complex question; 16) tu quoque; 17) ambiguity; 18) non sequitur. See in detail: K.W. Saunders, Informal Fallacies in Legal Argumentation, "South California Law Review", 1992-1993, Vol. 44, , pp. 343-382. Besides these, Saunders mentioned another one, namely, argumentum ad baculum which is - at least as per him - so rarely used in legal argumentation that he did not deal with it. Actually, fallacies 1)-3), 5), 9), 15) and 16) (and, of course, argumentum ad baculum) are not even in theory able to play a role in norm-logic argumentation, that is, statutory interpretation because they presuppose a dispute over factual issues between two parties with counterinterests; 4) merges into the interpretation by concrete works of jurisprudence or legal literature (see below); and 10 ) is, in part, indeed acceptable in legal interpretation (however, not as a logical one) since, for example, historical interpretation or the interpretation in accordance with former judge-made law count, in fact, in argumentum ad antiquitam.

16 According to argumentum a minori ad maius if a minor, less serious, less harmful act is forbidden then the major, more serious, more harmful act is also, or even more, forbidden whether or not the text contains this latter literally. Argumentum a maiori ad minus is the reciprocal of the preceding standard meaning that if a major, more serious, more harmful act is permitted then the minor, less serious, less harmful act cannot be prohibited either. ("Cui licet quod est plus licet utique quod est minus."; "Plus semper in se continet quod est minus.") Argumentum ad absurdum orders the ban of using those methods the application of which would lead to an absurd, impossible, inconsistent or undesirable consequence. Pursuant to argumentum a contrario if a social relation $(x)$ is regulated somehow $\left(x^{\prime}\right)$ then the complement relation thereof $\left(x^{\prime}\right)$ must be regulated contrarily (non- $\left.x^{\prime}\right)$. In the end, argumentum a simili (or argumentum a pari ratione) means that if there is a rule for a social relation existing and there is another rule for another social relation missing then the former rule can be applied for the latter, literally non-regulated, social relation as well. Furthermore, I do not perceive analogical interpretation (argumentum per analogiam) as a separate interpretation method but, simply, as a part of the maxim of argumentum a simili.

17 Such can be the maxim of implied powers, which means that if a provision gives a state organ a task then this organ must be regarded as if it was also given the authority to do that. In addition, the argumentum ab inconvenienti requires "law to be used to bring about, as efficiently as possible, good and useful effects in society" and, as, virtually, a part of this medhod, argumentum ab impossibili means that impossible inferences are not permissible, i.e., it is impossible and, consequently, improper to attribute a certain sense and its opposite meaning to a given legal text at the same time By the way, these maxims might as well be considered a special part 
the historical interpretation which uses the intent of the actual law-maker(s) in order to reveal the 'right' meaning of a statute ${ }^{18}$. In pursuance of the latter, one can adduce for either ( $7 / A$.) the regulatory justification (by the ministry or state secretariat that introduced the bill at issue), or (7/B.) the legislative history, that is, materials used for the drafting of the bill, or $(7 / C$.) the intent of the lawmaker in general, or (7/D.) the social context of the enactment (or the modification) of the statute to be interpreted.

The 8th method is the interpretation by concrete works of jurisprudence or legal literature ${ }^{19}$, the 9 th one is the interpretation on the basis of constitutional rights, principles, values and constitutional court decisions. The 10th one is the interpretation as per international treaties, covenants and conventions $\mathrm{s}^{20}$; the 11th method is the comparative legal interpretation ${ }^{21}$; the 12 th one is the interpretation via general principles ${ }^{22}$, the 13 th one is the substantive interpretation (referring

of argumentum ad absurdum (cf:: A.A. Leff, The Leff Dictionary of Law: A Fragment, "Yale Law Journal", 1984-1985, Vol. 94, pp. 2056).

18 The difference between them is that the former is an objective method in the sense that the aim is in the preamble or in the text of the statute itself, visible to everyone, while the latter, however, is out of any formal legal text, discoverable only in the social circumstances of the time of enactment and in the materials of the so-called 'legislative history' ('travaux préparatoires'), e.g. committee reports, texts of MPs' speeches etc.

19 This kind of technique, in contrast to the dogmatic, that is, legal professional interpretation, defines the meaning of a given text by either the legal scholars' steady opinion or, typically, by some concrete scholary work, including not only jurisprudential works, e.g. monographs, books, articles, notes, comments etc., but also commentaries (be them official or not), old, abolished statutes that regulated similar social relations, new, would-be norms which have not entered into force, and draft statutes that are not in effect or even those that surely never will be enacted.

20 In respect to this method, only those international treaties etc. have relevance which have been incorporated into the domestic legal system, that is, which are ratified and promulgated.

21 This kind of interpretation is a rather diffuse argument that contains, theoretically, the reference to other states' legal rules in general, to the international legal practice, to the European legal practice (as of, chiefly, the member states of the European Union or the Council of Europe), to the judicial practice or generally accepted customs of the 'democratic countries' or the 'modern constitutional states' on the whole, to some concrete norms of a concrete foreign legal system (which usually only underlies the results of the use of other techniques) etc. This method does not consist of those positive legal rules and legal documents (e.g. international conventions whose member is the EU itself, treaties, regulations, directives, decisions, framework decisions etc.) accepted or enacted by the EU or some organ thereof.

22 These principles ('regulae iuris') are such standards which are out of the legal texts of single acts or decrees, that is, which are characteristic of the entire legal system or some branches of law without being expressed in any authoritative source of law. E.g.: "Ignorance of the law excuses no one. ("Ignorantia legis neminem excusat."); "No one is bound to do the impossible." ("Nemo potest ad impossibile obligari."); "No one can transfer a greater right than he himself has." ("Nemo plus iuris ad alium transferre potest quam ipse habet.") in the civil law; the principle that "the judge has a duty to decide"; the principle of 'equality of arms' ("Non licet actori quod reo licitum non exsistit.") in the criminal procedure law etc. 
to some generally established material source of law) ${ }^{23}$, and the 14th one is the pool of other, legal system-specific methods ${ }^{24}$.

Of course, the above-mentioned methods are not 'pure' techniques at all, quite the contrary, in the course of practical argumentation they indeed overlap each other, therefore, the delimitation of these arguments can only be relative. This is the case also because in the judicial practice the arguments used in order to establish the 'real' meaning of a statute are rarely explicated by the courts. Hence, the analysts have to reconstruct the methods applied by the courts $e x$ post facto, that is, subsequently, which renders revealing and identifying these techniques more difficult.

\section{An empirical research into the practice of the Hungarian courts relating to statutory interpretation}

The grounds for the statements of the present paper are provided by the empirical legal sociological research that I pursued in 2009 and 2011 in order to find out what kind of interpretational methods and in what proportion are employed by Hungarian higher courts, and, mainly, by the late Supreme Court of Hungary (in its present name: the Curia) in the judicial practice. To achieve this goal, I have selected a set of case decisions from the official bulletin of the Supreme Court of Hungary (at present: Curia) titled 'Bírósági Határozatok' ['Judicial Decisions'] (abbreviated and hereafter: BHs). Every month a new issue of $\mathrm{BH}$ is published with the latest sentences pronounced by the Supreme Court (Curia) or, seldom, either of the five high courts of appeal ${ }^{25}$. I have chosen the BH's first 3 issues (January, February, March) from the year of 2009 and the first 4 issues (January, February, March, April) from the year of 2011. These issues

23 In cases of substantive interpretation the interpreter applies those arguments which serve and enforce such values that are highly recognized throughout the given society. These values can be cardinal moral principles, justice considerations, the idea of equality, policy implications, criteria of utility (e.g. mere economic points of view), the enforcement of common values (or purely the representation of the interest of the majority) etc. These sources of interpretation, however, are such values which can be invoked failing all else, that is, when the judge, facing the literal meaning of the legal text to be applied, would get to an unjust, immoral, uneconomical etc. result but he/she does not want to do it, and he/she does not have any other method at hand to apply.

24 As for the Hungarian law, such method is, for example, the interpretation via European Union legal rules (regulations, directives, decisions etc.). As for other legal systems, e.g. in the component states of a federation, such methods can be the interpretation by federal rules, federal judge-made law, the legislative history of similar subjected federal laws etc.

25 In Hungary, the judiciary has four levels: local courts (municipal courts or district courts), general courts, high courts of appeal and the Curia (the late Supreme Court of Hungary). 
contained altogether 217 case decisions $^{26}$ the methodological analysis on all of which I performed. These issues contain all the criminal (both substantive and procedural) law, civil (both substantive and procedural) law, economic law, labour law as well as administrative law cases, thus, those 217 case decisions included in these seven issues cover all the possible case types. Hence, taking samples can be regarded as representative.

Since I use the term 'interpretation' in its narrowest sense (sensu stricto), that is, I mean that only in those cases are there any interpretation where the judge explains the meaning of an ambiguous or vague statutory term, expression or longer text (which can otherwise be interpreted in several different ways) in the opinion of the court, I exclude from the territory of the meaning of the term 'interpretation' those cases in which the court does not pursue such kinds of activity, e.g. which includes only norm-logic syllogism(s), using Wróblewski's denomination, subsumption syllogism $(\mathrm{s})^{27}$, that is, plainly mechanical application of legal norms or which plainly consists of laying down the real facts of the case. Of the 217 cases that I examined, I found altogether 21 such kinds of judgements, hence, there were only 196 decisions which did contain statutory interpretation in its narrowest sense.

As particularly to the frequency of the instances in the above-mentioned method types, it can definitely be laid down that during the statutory interpretation the most typical, most often applied argument is the grammatical interpretation (1.) ${ }^{28}$. Among the subtypes of this manner, the interpretation in accordance with ordinary meaning (1/A.) and the legal professional (dogmatic) interpretation $(1 / B$.$) are of especially great importance. There are references to the former in$ about one-third of the cases and to the latter in approximately two-thirds thereof. However, the interpretation in accordance with other (non-legal) professions' technical terms is slightly characteristic of the adjudication activity of Hungarian higher courts. In the course of the interpretation via ordinary meaning, the semantic one is the dominant way, this sort of method was applied in $68 \mathrm{BHs}$ (that is, officially reported higher court case decisions; hereafter referred to as: ' $\mathrm{BHs}$ '), that is, in the $31.34 \%$ of the cases analysed ${ }^{29}$. In contrast thereto, syntactic

26 Of them, 95 decisions were pronounced in 2009 and 122 in 2011.

27 See: J. Wróblewski, Legal Syllogism and Rationality of Judicial Decision, "Rechtstheorie", 1974, no. 1, pp. 43-44.

28 Henceforward, for the sake of lucidity, I will always indicate the number of the interpretational method being discussed.

29 From the sampled case decisions of 2009 these are (some examples are given in parentheses): BH (no.) 2, BH 3, BH 5, BH 9, BH 19, BH 20, BH 21, BH 30, BH 32, BH 34, BH 35, BH 37, $\mathrm{BH} 41$ (what 'disposing of as his own a thing' means regards to the crime of 'embezzlement' in Section 317 of the Act of 1978 on the Criminal Code [of Hungary]), BH 42 (when the 'danger of 
interpretation, that is, the interpretation by right of copulatives, happened in my sample only 7 times (in $3.23 \%$ of the cases reviewed). Of these latter, in one $\mathrm{e}^{30}$ the Supreme Court [SC] decided that an assertive sentence in a legal norm is equivalent with an imperative sentence, namely, when a legal norm describes a situational behavior, it orders the consignee to act like that. In two others ${ }^{31}$ the Supreme Court analysed the forms of conjunction declaring that not only the phrase 'and' but the words 'besides', 'too' etc. should be regarded as conjunctions, that is, a legal entitlement or a legal obligation comes into existence only in cases if all the elements of the hypothesis of a legal rule are fulfilled. In another one $^{32}$ the SC declared for the term 'because of' to be a copulative expressing the dependence of an effect upon a cause. There was such a case ${ }^{33}$ as well in which the court explained the possible meanings of the expression 'or ${ }^{34}$, and another one $^{35}$ in which the SC stated if a law spoke in plural form, there could not only be one subject in the regulated legal relationship.

Legal professional (dogmatic) interpretation (1/B.) was altogether in $141 \mathrm{BHs}$ $(64.98 \%)^{36}$, and within it simple conceptual (dogmatic) interpretation (1/B.a.)

repeating a crime' is real, according to the everyday experiences), $\mathrm{BH} 45$ ('the difference between the value of a service and the consideration due' in which cases 'is grossly unfair', precisely, in the concrete case, whether or not a triple difference could be regarded as 'grossly unfair' in view of section 201 of Act IV of 1959 on the Civil Code [of Hungary]), BH 56 (can be a 21-hour daily work regarded as a 24-hour, that is, non-stop, daily work? [the judicial answer, on the ground of common sense, was no]), BH 62, BH 66, BH 69 (only being aware of a crime committed does not make this person 'accomplice', that is, a person who knowingly and voluntarily helps another person commit a crime), BH 71, BH 73, BH 81, BH 82, BH 83, BH 85, BH 86, BH 89, BH 93, BH 94; from the sampled case decisions of 2011 these are: BH 1, BH 2, BH 4, BH 15, BH 17, BH 18, BH 23, BH 24, BH 26, BH 29, BH 30, BH 31, BH 32, BH 33, BH 39, BH 46, BH 47, BH 50, BH 54, BH 61, BH 65, BH 68, BH 71, BH 72, BH 76, BH 78, BH 83, BH 84, BH 87, BH 89, BH 93, BH 95, BH 104, BH 105, BH 109, BH 114, BH 117.

30 BH 31/2009.

31 BH 34/2009, BH 49/2011.

$32 \mathrm{BH} \mathrm{40/2009.}$

33 BH 80/2011.

34 The copulative 'or' can refer either to alternation (when a legal norm is applicable provided either of the elements of the hypothesis of a legal rule is fulfilled) or to disjunction (when a legal norm is applicable if and only if the elements of the hypothesis of a legal rule is fulfilled). As for the distinction of alternation and disjunction see: L. Bárdi, Jogi logika [Legal logic], Eötvös József Könyvkiadó, Budapest 2009, pp. 45-51.

35 BH 119/2011.

36 From 2009: BH 1, BH 2, BH 3, BH 4, BH 5, BH 8, BH 9, BH 13, BH 14, BH 15, BH 17, BH

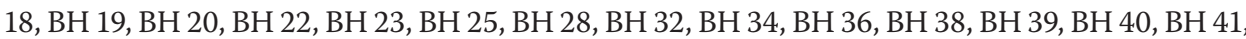
BH 43, BH 44, BH 45, BH 46, BH 47, BH 48, BH 49, BH 50, BH 51, BH 52, BH 53, BH 54, BH 55, BH 56, BH 57, BH 58, BH 60, BH 63, BH 64, BH 65, BH 66, BH 67, BH 69, BH 70, BH 71, BH 72, BH 73, BH 74, BH 75, BH 76, BH 77, BH 78, BH 80, BH 86, BH 89, BH 91, BH 92, BH 94; from 2011: BH 2, BH 3, BH 6, BH 7, BH 9, BH 12, BH 14, BH 15, BH 16, BH 17, BH 20, BH 22, BH 25, BH 27, BH 28, BH 30, BH 31, BH 32, BH 33, BH 34, BH 35, BH 38, BH 39, BH 40, BH 41, BH 45, BH 51, BH 52, 
happened 79 times $(36.41 \%)^{37}$, interpretation explicitly by principles of statutes or branches of law (1/B.b.) befell in $18 \mathrm{BHs}(8.29 \%)^{38}$, and contextual interpretation in its broad sense (1/B.c.) occurred in 98 cases $(45.16 \%)^{39}$, with 10 times $(4.61 \%)$ on the ground of either of the so-called 'derogation formulas' ${ }^{20}$ and 3 times $(1.38 \%)^{41}$ by right of constitution-conform interpretation therein ${ }^{42}$.

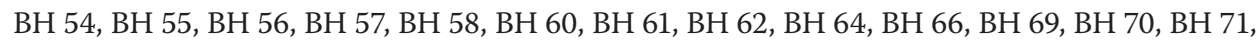
BH 72, BH 73, BH 75, BH 76, BH 78, BH 79, BH 81, BH 83, BH 85, BH 87, BH 88, BH 90, BH 91, BH 92, BH 93, BH 94, BH 97, BH 98, BH 100, BH 101, BH 102, BH 103, BH 104, BH 105, BH 106, BH 107, BH 109, BH 110, BH 111, BH 112, BH 113, BH 114, BH 115, BH 116, BH 117, BH 119, BH 122.

37 Of BHs from 2009: BH 2, BH 5, BH 15, BH 17, BH 20, BH 22, BH 23, BH 28, BH 36, BH 38, BH 39, BH 40, BH 41, BH 45, BH 46, BH 47, BH 49, BH 51, BH 52, BH 53, BH 54, BH 55, BH 56, BH 57, BH 69, BH 71, BH 72, BH 73, BH 74, BH 75, BH 94; and of BHs from 2011: BH 3, BH 7, BH 14, BH 15, BH 17, BH 20, BH 22, BH 25, BH 28, BH 30, BH 31, BH 32, BH 33, BH 35, BH 41, BH 45, BH 52, BH 54, BH 56, BH 57, BH 60, BH 61, BH 62, BH 64, BH 69, BH 70, BH 71, ВH 75, BH 81, BH 84, BH 87, BH 91, BH 92, BH 93, BH 97, BH 100, BH 101, BH 102, BH 103, BH 104, BH 106, BH 107, BH 109, BH 110, BH 113, BH 114, BH 117, BH 122.

38 These BHs are the following (with some examples in parentheses). From 2009: BH 4, BH 45, BH 64 (general principles of taxation), BH 69 (nullum crimen sine culpa), BH 70, BH 73, BH 76, BH 92 (exercising rights and fulfilling obligations by good faith in the election process). And from 2011: BH 6, BH 27, BH 28 (the right to seek remedy, the prohibition of curtailment of authorities and competences), BH 30 (in dubio pro reo), BH 55, BH 57, BH 62, BH 104, BH 107, BH 122 (the principle of 'documentation' in Act CXLI of 1997 on Real Estate Registration).

39 In 2009: BH 1, BH 3, BH 4, BH 5, BH 8, BH 9, BH 13, BH 14, BH 15, BH 17, BH 18, BH 19, BH 20, BH 22, BH 23, BH 25, BH 32, BH 34, BH 36, BH 38, BH 43, BH 44, BH 45, BH 46, BH 48, BH 49, BH 50, BH 53, BH 55, BH 56, BH 58, BH 60, BH 63, BH 65, BH 66, BH 67, BH 70, BH 73, BH 74, BH 76, BH 77, BH 78, BH 80, BH 89 (among an act and an EC directive), BH 91; In 2011: BH 2, BH 7, BH 9, BH 12, BH 15, BH 16, BH 27, BH 28, BH 30, BH 32, BH 34, BH 38, BH 39, BH 40, BH 42, BH 44, BH 48, BH 51, BH 54, BH 55, BH 58, BH 62, BH 66, BH 67, BH 69, BH 70, BH 71, BH 72, BH 73, BH 75, BH 76, BH 78, BH 79, BH 83, BH 84, BH 85, BH 87, BH 88, BH 90, BH 94, BH 98, BH 102, BH 104, BH 105, BH 109, BH 111, BH 112, BH 115, BH 116, BH 117, BH 119 , BH 121 (exclusively among European Union legal rules), BH 122.

40 Of them the Hungarian higher courts employed the maxim of lex specialis derogat legi generali in 7 BHs, namely in BH 19 and BH 86 of 2009, and BH 16, BH 42, BH 44, BH 87 and BH 109 of 2011 without, except for the last one, explicating the maxim applied. In the BH 54/2011 employed lex posterior derogat legi priori, the BH 76/2009 used a special form of contextual interpretation mixing the principle of lex specialis derogat legi generali and the principle of lex superior derogat legi inferiori declaring that an act can be derogated by an implementation decree of the Minister of Justice the latter of which established the particulars pursuant to the authorization conferred by a law promulgating an international treaty. In the end, in BH 62/2011 another specific interpretation occurred when the SC arranged the collision between the precept of lex superior and the maxim of lex specialis stating that the application of the former precedes that of the latter, namely, if a superior source of law implies a generally formulated rule, then this derogates a legal norm which stands at a lower level in the hierarchy of sources of law but which is special, as compared to the former one.

41 BH 15/2011, BH 104/2011, BH 105/2011.

42 This method is frequently used by German courts called 'verfassungskonforme Auslegung'. Since in Germany there exists the so-called 'real constitutional complaint', that is, the kind of motion with which one can challenge the constitutionality of a final judicial decision and, as 
However, interpretation in accordance with other (non-legal) professions' technical terms (1/C.) occurred not more than on 4 occasions $(1.84 \%)$. For instance, in BH 1/2009 the High Court of Appeal of Szeged ruled that property equals to all the assets which the perpetrator possessed and were connected to the commission of a crime. Precisely, in this case the most important question was whether the criminal sanction of 'civil forfeiture', according to paragraph a) of subsection (1) of section 77/B of Act IV of 1978 on the Criminal Code ${ }^{43}$, can be imposed on a drug dealer and whether he can be deprived of his money which he had not gained from selling narcotic drugs but which he had spent to buy drugs in order to trade with them. That is, the court had to decide if property meant only the gains, which otherwise is inferred from the literal meaning of the given regulation, or it also covered the sum that had been possessed by the offender before he spent it for buying drugs.

Eventually, the court interpreted this provision contrary to its literal meaning and stated that the term 'property' means not only the profit, that is, income minus costs, but all the assets which were connected to drug trafficking, including the offender's former property as well. In the course of deciding this matter, the court used the economic meaning of the expression 'property' instead of the literal legal meaning. Furthermore, argumentations via non-legal technical

\footnotetext{
a consequence thereof, try to nullify the given sentence if being personally concerned and interested, much experience can be gained from the German practice. For more details of the German practice and principles of 'verfassungskonforme Auslegung', see e.g.: E. Denninger, Judicial Review Revisited: The German Experience, "Tulane Law Review”, 1984-1985, Vol. 59, pp. 1013-1031; F. Bydlinski, Legal methodology and the concept of law, Springer-Verlag, Wien-New York 1982, pp. 455-457. For the difficulties, hardships and dangers, see the critiques of this method: as for the German' Verfassungsbeschwerde ('constitutional complaint'): U. Diederichsen, The Federal Constitutional Court as the supreme civil court: A study on legal methodology, [in:] Archiv für die civilistische Praxis, Bd. 198 (1998), pp. 171-260; as for the Spanish 'amparo': E.G. Lopez, Judicial Review in Spain: The Constitutional Court, "Loyola of Los Angeles Law Review", 2008, Vol. 41, pp. 557-559; L. Turano: Quis Custodiet Ipsos Custodes?: The struggle for jurisdiction between the Tribunal Constitucional and the Tribunal Supremo, "International Journal of Constitutional Law", 2006, Vol. 4, Issue 1, pp. 151-162; as for similar legal institutions of other countries: M. Bobek, Quantity or Quality: Re-Assessing the Role of Supreme Jurisdiction in Central Europe, "EUI Working Paper Law", 2007, no. 36; A.S. Stone, Governing with Judges: Constitutional Politics in Europe, Oxford University Press, Oxford 2000, pp. 114-126; L. Garlicki, Constitutional courts versus supreme courts, "I•CON", 2007, Vol. 5, no. 1; Z. Kuhn, Making Constitutionalism Horizontal: Three Different Central European Strategies, [in:] The Constitution In Private Relations: Expanding Constitutionalism, eds. A. Sajó, R. Uitz, Eleven International 2005, pp. 217-240; P. Holländer, The Role of the Constitutional Court for the Application of the Constitution in Case Decisions of Ordinary Courts, "Archiv für Rechts- und Sozialphilosophie", 2000, Vol. 86, Heft 4, pp. 537-552.

43 As per this provision, "[t]he following shall be subject to civil forfeiture: any financial gain or advantage resulting from criminal activities, obtained by the offender in the course of or in connection with, a criminal act [...]".
} 
meaning eventuated in the text of the opinion of $\mathrm{BH} 60 / 2009$, BH 13/2011 and BH 39/2011, adopting labor safety/occupational public health, polytechnic and economic based technical interpretation, respectively.

The inner proportions of the grammatical interpretation are hardly surprising. It is rather obvious that an organ that interprets legal norms will start from the legal meaning of the words, expressions etc. contained therein while trying to establish what a given term etc. means. Since single legal provisions stand on their own very seldom, contrasting the sense thereof with the meaning of other legal regulations is indispensable, at least in most instances. The almost 50 percent ratio of contextual interpretation in its broad sense can be attributable to this fact. Nevertheless, there are also numerous legal terms which do have strict and unequivocal professional (legal jargon, that is, dogmatic) definition and content, and these kinds of legal expressions have to be applied in the light of this unequivocal meaning. Indeed, during the period analysed, it occurred in nearly one-third of the cases in the practice of the Hungarian higher courts, and, mainly, of the Supreme Court of Hungary.

As compared to the above, principles of statutes or branches of law play auxiliary role since they are invoked only in cases where there are no unambiguous legal technical meanings or, more rarely, if the legal dogmatic sense seems, in the case in question, to contradict any principles of statutes or branches of law to such an extent that the judicial decision on the very score of the established and conventional conceptual meaning would impugn the existence of the given legal principle itself. Besides the legal dogmatic meaning, however, it is also indispensable for proper and pertinent interpretation to take the ordinary meaning, too, as a baseline ${ }^{44}$. The cause of it is that statutory texts are also parts of

44 For the 'ordinary meaning' as plain meaning as a kind of golden rule for interpretation of any statutory text, see.: A. Scalia, A Matter of Interpretation: Federal Courts and the Law, ed. A. Gutmann, The University Center for Human Values Series, Princeton University Press, Princeton, New Jersey 1997. Scalia is the chief representative of the theory of textualism the devotees of which adhere to the pure text of statutes. However, textualism cannot be regarded as a totally uniform school. According to Roger Colinvaux, there are three streams thereof: textualism (without any modality), structural textualism and hypertextualism. "A textualist finds law by defining the words of a statute in accord with their ordinary or plain meaning. Dictionaries and canons of construction are often helpful tools in this pursuit. A structural textualist finds law by examining the words not only in their ordinary sense, but also by looking at the structure of the statute as a whole [...]Finally, a hypertextualist finds law by utilizing the tools of the other forms of textualism, as well as by resorting to analysis of other statutes, as if statutes in general were a reference guide or a kind of dictionary for the meaning of legal words." R. Colinvaux: What is Law? A Search for Legal Meaning and Good Judging Under a Textualist Lens, "Indiana Law Journal”, Vol. 73, Issue 4, pp. 1133-1134.) For the textualist approach in general, see e.g.: P.J. Smith, Textualism and Jurisdiction, "Columbia Law Review", 2008, Vol. 108, pp. 1883-1948; C. Nelson, What is Textualism?, "Virginia Law Review", 2005, Vol. 91, pp. 347-418; W.N. Eskridge, 
the given language, thus legal norms, over and above those words and phrases bearing only or primarily with legal technical meaning, have to contain such expressions as well which have no specific dogmatic meaning at all, and what is more, in most cases they do have to include such kinds of terms. Moreover, these words and expressions have greater semantic vagueness, hence, it occurs relatively frequently that one has to interpret such a term contented by a statute which has only ordinary semantic meaning. I found such kind of interpretation in one-third of the cases analysed. Compared thereto, interpretation by nonlegal technical meaning happens exceptionally seldom, generally (but, of course, not exclusively) in cases where the subject of a legal norm or a legal provision is a social relation which is connected with some special though non-legal profession. The less than two percent ratio of the occurrences of the interpretation via non-legal technical sense verifies this statement adequately.

I found contextual interpretation in its narrow sense (2.), that is, interpretation of a legal norm on the score of the designation that derives merely from the emplacement of the interpreted provision in the system of the legal norms, altogether only in $8 \mathrm{BHs}^{45}$, that is, in $3.69 \%$ of the $\mathrm{BHs}$ reviewed. For instance, in BH 26/2009 the SC argued that the rules of Hungary's Labor Code can be interpreted exclusively in context with other rules concerning employment (labor) relationship, and the interpretation thereof in context with rules of company law not being allowed, viz., these latter regulations concern other, non-labor, relations. In BH 56/2009 the Supreme Court, similarly, decided on the grounds of where the applicable legal institution lies within the system of the Health Care Act, more precisely, on the basis of where the lawmaker regulated this legal institution; in which chapter, title and subtitle of that statute. In BH 64/2009 the $\mathrm{SC}$ ruled that if the same term turns up in two (or more) legal norms, the concept defined by one statute cannot be extrapolated to the application of another statute's definition in the course of enforcing the former regulation ${ }^{46}$. In

The New Textualism, "UCLA Law Review", 1989-1990, Vol 37, pp. 621-691. For the critiques of textualism, see e.g.: A.S. Greene, The Missing Step of Textualism, "Fordham Law Review", 2005-2006, Vol. 74, pp. 1913-1936; S. Sherry, Textualism and Judgement, "The George Washington Law Review", June/August 1998, Vol. 66, no. 5/6, pp. 1148-1152; D.A. Strauss, The New Textualism in Constitutional Law, “The George Washington Law Review”, June/August 1998, Vol 66, no. 5/6, pp. 1153-1158. In the end, the neatest counter-opinion was formulated by Martin Redish, who wrote that "we should not let the dead hand of the past control us". M.H. Redish, Interpretivism and the Judicial Role in a Constitutional Democracy: Seeking an Alternative to Originalism, "Harvard Journal of Law and Public Policy", Winter 1996, Vol. 19, no. 2, pp. 525-532.

45 BH 26/2009, BH 56/2009, BH 64/2009, BH 75/2009, BH 94/2009, BH 46/2011, BH 69/2011, BH 91/2011.

46 In this particular case this was the concept of 'habitation'. 
BH 75/2009 the High Court of Appeal of Szeged had to decide whether or not the defendant who was accused of 'influence peddling ${ }^{37}$ had indeed committted that criminal offence. While considering this case, the court interpreted this provision by virtue of where the legislator had placed this regulation within the system of the Criminal Code, that is, what kind of other provisions surrounded the offense of 'influence peddling' in the same title of the same chapter of the Crininal Code, namely, what these other crimes' purpose and legal object was. As can be seen from the examples mentioned here this kind of interpretation is frequently pervaded by the respect of the purposes and legal political goals of the given statute or lone provision.

Contrary to the contextual interpretation in its narrow sense, but likewise the grammatical arguments, references to one or more elements of judge-made law is pretty abundant. If Béla Pokol, former researcher of the matter of statutory interpretation, states in a 1999 article that "[i]n the last twenty years Hungarian courts decided in more and more cases not purely on the very basis of the statutory text but by virtue of the Supreme Court's former case decisions and the judicial practice as well" ${ }^{48}$, then my research does corroborate this ascertainment. Indeed, the use of former judge-made interpretative decisions in pursuance of current sentencing seems to be more and more dominant and it becomes more and more important that a legal problem be solved by right of how the (higher) courts and, mainly, the Supreme Court itself, decided in previous similar cases.

As to the interpretation in accordance with former judge-made law $(3 .)^{49}$, one has to distinguish between the references to the former case decisions as 'precedents', to the former judicial practice, and to the judge-made abstract norms ('directives' ['irányelvek'], 'principled rulings' ['elvi döntések'], 'college positions' ['kollégiumi állásfoglalások'], 'law unification decisions' ['jogegységi határozatok'], 'college opinions' ['kollégiumi vélemények'], 'decisions in principle' ['elvi bírósági határozatok']. Since these interpretative judicial norms could occur either on their own or in any combination, it is useful to first have a look at separately, in what proportion the different combinations occur in the course of the interpretation of statutory texts, then to examine independently how

47 According to section 256 of the Hungarian Criminal Code, "[a]ny person who - purporting to influence a public official - requests or accepts an unlawful advantage for himself or on behalf of another person is guilty of a felony [...]"

48 B. Pokol, A jogértelmezés alapjai, "Magyar Jog”, 1999, no. 11, p. 496.

49 For the main differencies between Anglo-Saxon common law and Hungarian judge-made law, see e.g.: O. Bohanek, Comparative legal aspects of the English Common Law system and the Hungarian Roman-German legal regime, with an emphasis in regards to the constitutional differences in criminal justice, "Jogelméleti Szemle", 2010, no. 1, http://jesz.ajk.elte.hu. 
many references were made altogether, either in themselves or besides invoking other judge-made forms of law, to case decisions, to the judicial practice, and to judicial abstract norms.

Interpretation in accordance with former judge-made law in the sample analysed befell (in one BH might as well several times) on 76 occasions $^{50}$, that is, more than one-third of the cases (35.02\%). Of them references exclusively to the judicial practice (3/A.) eventuated in $21 \mathrm{BHs}(9.68 \%)$ altogether 27 times $^{51}$; separate interpretation according to former case decisions as 'precedents' (typically to former BHs) (3/B.) occurred in 26 cases (11.98\%) 37 times $^{52}$; and argumentation by right of one or more judge-made abstract norms (3/C.) eventuated in 29 court decisions (13.37\%) altogether on 32 occasions $^{53}$. Interpretation by virtue of both sentencing practice and, underlying it, concrete precedents (3/D.) happened in $21 \mathrm{BHs}(9.68 \%) 22$ times $^{54}$; interpretation via both sentencing practice and, corroborating it, judicial abstract norms (3/E.) befell in $7 \mathrm{BHs}(3.23 \%)$ on the same number of occasion ${ }^{55}$; references to both judicial abstract norms and, conforming them, concrete case decisions (3/F.) occurred only in 3 cases $(1.38 \%)^{56}$; in the end, there were altogether $5 \mathrm{BHs}$ that judges applied for reasoning their decisions using all the three elements of judge-made law simultaneously, namely, sentencing practice, judicial abstract norms and, underlying the former ones, court case decisions (3/G. $)^{57}$.

Now putting together the parts of the judge-made law, as for the absolute frequency one can see the picture as follows. The interpretation on the basis of

50 In 2009: BH 3, BH 5, BH 9, BH 13, BH 15, BH 20, BH 21, BH 25, BH 33, BH 34, BH 37, BH 38, BH 41, BH 44, BH 46, BH 47, BH 49, BH 50, BH 51, BH 52, BH 55, BH 57, BH 60, BH 63, BH 69, BH 71, BH 72, BH 73, BH 74, BH 75, BH 76, BH 77, BH 78, BH 84, BH 90. In 2011: BH 1, BH 3, BH 5, BH 7, BH 13, BH 20, BH 21, BH 28, BH 29, BH 30, BH 31, BH 32, BH 34, BH 36, BH 40, BH 41 (2 db), BH 42 (2 db), BH 44, BH 47, BH 52, BH 57, BH 59, BH 61, BH 63, BH 67, BH 71, BH 72, BH 74, BH 75, BH 76, BH 82, BH 83, BH 89, BH 92, BH 97, BH 100, BH 104, BH 105, BH 107, BH 111, BH 113.

51 In 2009: BH 5, BH 9, BH 15, BH 34, BH 37, BH 38, BH 46, BH 47, BH 49, BH 52, ВН 69 , BH 74, BH 75, BH 77, BH 90; in 2011: BH 30, BH 31, BH 42, BH 61, BH 89, BH 113.

52 From 2009: BH 20, BH 25, BH 37, BH 41, BH 49, BH 60, BH 63, BH 71, BH 76, BH 78. From 2011: BH 3, BH 13, BH 20, BH 21, BH 29, BH 30, BH 36, BH 41, BH 44, BH 63, BH 76, BH 97, BH 100, BH 104, BH 105, BH 107.

53 In 2009: BH 3, BH 5, BH 15, BH 20, BH 21, BH 31, BH 36, BH 38, BH 50, BH 51, BH 52, BH 57, BH 71, BH 72, BH 74, BH 84; in 2011: BH 1, BH 28, BH 34, BH 40, BH 59, BH 72, BH 74, BH 75 (PJE), BH 76, BH 82, BH 92, BH 111, BH 113.

54 From the year of 2009: BH 13, BH 25, BH 33, BH 44, BH 49, BH 57, BH 73, BH 74, BH 75; and from 2011: BH 3, BH 5, BH 32, BH 36, BH 41, BH 52, BH 59, BH 67, BH 71, BH 72, BH 97, BH 107.

55 BH 55/2009, BH 74/2009, BH 84/2009, BH 47/2011, BH 57/2011, BH 67/2011, BH 105/2011.

56 BH 72/2011, BH 83/2011 and BH 117/2011.

57 BH 25/2009, BH 57/2009, BH 7/2011, BH 13/2011, BH 42/2011. 
either the judicial practice, or the former concrete case decisions, or the judicial abstract norms has a similar prevalence, albeit the references to judicial abstract norms are of a slightly lesser occurrence. Namely, while references to former case decisions, either on their own or besides the other two kinds of judicial norms, occurred in 55 BHs (25.35\%) 67 times in all, and the interpretation by virtue of existing judicial practice, either unaccompanied by or together with the other two kinds of judicial norms as well, happened in $54 \mathrm{BHs}(24.88 \%)$ on 61 occasions, argumentation on the basis of former judicial abstract norms befell, either on their own or besides the other two kinds of judicial norms, 'solely' in 44 BHs (20.28\%) 47 times altogether.

As for the interpretation in accordance with other (non-judicial) public authorities in the administration of justice (4.), this method is not typical in the Hungarian legal system. It is alien from the Hungarian courts' sentencing activity and the Hungarian legal culture on the whole for judges to use executive acts, administrative or other kinds of law enforcement organs' principled directions (which were often made for internal application), or foreign sentencing authorities' decisions (that are frequently not compulsory for either Hungarian courts or Hungarian citizens, or that are not compulsory in their normative sense except for particular cases) in order to determine what a legal text with ambiguous purport 'actually' means.

For instance, interpretation as per public authorities' principled decisions (4/A.) in the sampled cases did not occur at all. Even so, it is not groundless to insert this sort of method of argumentation into the classification presented above since, though the Hungarian courts did not refer to this technique in any of the cases, plaintiffs did it in two suits, in such a way that acceptance of this argumentation by the courts could not be considered $a b$ ovo excluded, that is, could not be regarded as undisputedly unjustified. On the one hand, in BH 19/2009 the plaintiff in a competition law case concerning the Hungarian Competition $\mathrm{Act}^{58}$ referred to the $32 / 2005 \mathrm{Vj}$. Resolution of the Hungarian Competition Authority's Competition Council, which reference the Supreme Court did not accepted in the end. On the other hand, similar allusion occurred by the suitor during the trial in the case of BH 91/2009 to 2/2003 Statement of the President of the Hungarian Competition Authority so as to interpret the legal regulation in Section 78 of the Competition Act, albeit, as mentioned previously, the Supreme Court did not recognise the applicability of this argumentation, either.

58 In its whole title: Act LVII of 1996 on the Prohibition of Unfair Trading Practices and Unfair Competition. 
Interpretation as per other domestic administrative organs' case decisions and declared opinions (4/B.) befell only twice (0.92\%), viz., in BH 81/2009 the $\mathrm{SC}$, accepting the respondent's suggestion how the applicable legal text should be interpreted, referring to one of the resolutions ${ }^{59}$ of the Parliamentary Commissioner for data protection and freedom of information (in the followings: ombudsman for data protection) as the basis for its decision, and in BH 69/2011 the Supreme Court also interpreted a data protection statutory rule by virtue of an opinion ${ }^{60}$ of, again, the ombudsman for data protection. In the end, the SC employed interpretation in conformity with judgements or sentencing practice of international judicial forums under the scope of their authority (4/C.) only in one case (0.46\%), namely, in $\mathrm{BH} 56 / 2009$ in which it justified its ruling and the argumentation underlying this ruling by the practice of the European Court of Human Rights (henceforward: ECHR) and, corroborating this practice, also referred to two particular case decisions of ECHR ${ }^{61}$.

The logical interpretation (5.) is a curious method, the characteristic of which is that man principally applies it tendentiously, that is, when the in terpreter, for he or she intuitively feels the literal meaning's consequences inappropriate, wishes to come to a result that is contrary to the given text's otherwise unambiguous literal meaning. From this aspect, the use of formal logic generally serves the rational solution of an interpretation dilemma by simple common sense. This means that the maxims of formal logic as the universal laws of human rationality and the regards of sound and sober thinking virtually coincide with each other. A further feature of logical interpretation is that the employment thereof is rarely explicated, videlicet, courts ${ }^{62}$ mostly use the logical arguments in such a way that they do not refer expressis verbis to the formula they applied. Either judges refer to these formulas or not, the maxims of formal logic are of great importance in the course of law enforcement, and not only considering their prevalence but, primarily, the significance of them. Formal logic is one of those few entities the rules of which are both irrefutable (since being objective), at least if the conditions of their application are definable, and general, that is, valid in each legal system and at any time ${ }^{63}$. For that very reason, in cases when one refers to them profoundly

59 2038/K/2006-2. Resolution.

$601234 / \mathrm{H} / 2006$. Opinion.

61 X v. Norway, no. 5923/72, Commission decision of 30 May 1975; Croissant v. Germany, no. 13611/88, Commission decision of 25 September 1992.

62 This is characteristic, of course, not only for judicial law enforcement activities, but also for every kind of argument.

63 Certainly, if the conditions of their application are not unequivocal, because, for example, one needs to pursue the preliminary evaluation of the given situation in order to be able to 
they count as solid arguments for the solution of the given interpretation dilemma. This is also the case in pursuance of deciding those cases in the course of which courts used logical formulas.

Interpretation by virtue of logical maxims eventuated in the sample examined in $37 \mathrm{BHs}(17.05 \%)$ altogether 44 times. These 44 occurrences split among the five practically relevant logical methods as follows: Argumentum a minori ad maius (5/A.) befell only in one case (0.46\%): in BH 62/2009 the Supreme Court ruled that if an act forbids a legal relationship (in this particular case the mayor's employment relationship) to be modified even by mutual consent then it does not allow for the same relationship to be modified unilaterally, either. Hungarian courts referred to argumentum a maiori ad minus (5/B.) also very seldom, only on two occasions (0.92\%), namely in BH 5/200964 and BH 119/2011. In this latter case the Supreme Court performed a classic set logical interpretation stating that if a feature, on the score of a legal norm's text, is attributable to a set then this must also be attributable to any subset being part of the whole set.

Interpretation via argumentum ad absurdum (5/C.), that is, the maxim under which, if the consequences of applying a given interpretation method were absurd, impossible, counterproductive or mutually exclusive, then this sense must be abjured ${ }^{65}$ and one must search for another, proper meaning ${ }^{66}$, was invoked

determine these conditions, then logic maxims cannot hel $\mathrm{p}$ the interpreter to ascertain what the text in question really means or what it surely does not mean. If so, we need meta-norms which specify (or possibly may not specify at all as well) those circumstances under which one or another formula may be applicable. This latter can occur if, under special conditions, the maxims of a contrario and a simili contradict one another.

64 This was the one and only case among the analyzed 217 ones in which the Supreme Court explicitly denominated a logical formula when applied.

65 From this point of view this techique is an odd-one-out amongst the so-called logical methods since this formula is in fact not logical in its narrow sense, videlicet, using it one ascertaines, not on the grounds of formal logic thinking but, instead, on the score of practical considerations, which one of the theoretically possibly employable meanings can or cannot be applicable in deciding the particular interpretation dilemma.

66 Du Plessis, originally only for the analysis and introduction of those presumptions on which the South African statutory interpretation rests, enumerates the possible requirements in the absence of which the application of any statute would be contradictory to the common sense, that is, it would be absurd to call them as 'interpretative aids'. According to him, these presumptions are the following [the numbering is from me - T.J.Z.]: (1) no enactment seeks to achieve unjust, unreasonable and inequitable results; (2) an enactment applies to general and not to particular instances; (3) an enactment seeks to promote the public interest; (4) an enactment does not interfere with the jurisdiction of the courts; (5) an enactment does not interfere with or violate the rules of international law; (6) an enactment does not bind the state; (7) an enactment does not amend the existing law beyond necessity; (8) an enactment does not obtain retroactively; (9) no enactment contains invalid or purposeless provisions; (10) references in an enactment to conduct are references to legally valid modes of conduct; (11) an enactment does not 
in 13 cases (5.99\%). For example, in BH 4/2009 the Supreme Court interpreted a Highway Code's regulation obligating all drivers to ply with due foresight and named this commitment as 'obligation for general prevention of accidents'. The $\mathrm{SC}$, however, stated this rule does not and may not mean that a driver in all circumstances has to do everything not to get involved in accidents even if he or she observed all particular provisions concerning his or her behavior during traffic whilst the injured pedestrian himself infringed the traffic regulations. In BH 12/2009 the SC regarding the legal institution of liability insurance pointed out that if the damaged party was not allowed to apply directly to the tortfeasor's insurance company for indemnification on the grounds of the tortfeasor legal person having been dissolved, then this sense would be contrary to the rationale of the legal institution of liability insurance. This statement is remarkable because the Hungarian Civil Code (Act IV of 1959) literally claims that "[ $t]$ he aggrieved person shall not be entitled to enforce his claim directly against the insurer"67, that is, the court's logical interpretation via argumentum ad absurdum was explicitly contradictory to the applicable statutory provision's plain literal meaning. In BH 57/2009 the Supreme Court, objecting to the secondinstance court's binding decision, ruled that if a deadline passes one under no condition may perform such procedural act (in this present case, file for annulment of an arbitration decision) which this deadline concerns. This is also the case even if the person concerned becomes aware of the facts underlying the possibility of this kind of legal action only after this term has been completed, otherwise the term of preclusion would lose its function to exist a specify final date when a case is terminated irrevocably and for good.

Argumentum a contrario, that is, the inference based on the contrary (5/D.), took place in $20 \mathrm{BHs}(9.22 \%)$ altogether on 22 occasions $^{68}$, being used principally for the interpretation of taxative enumeration. According to it, if a legal provision enumerates those elements which this rule relates to then this provision may be applicable for none of the elements omitted from this specification. Argumentum a simili, that is, conclusion by similarity (5/E.) occurred in $5 \mathrm{BHs}(2.30 \%)$, in all

obtain extraterritorially; (12) the same words and phrases in the same enactment bear the same meaning throughout. In fact, the presumption $\mathrm{Nr}$. (5) is neither necessary in a given legal system, nor does it belong to the principle argumentum ad absurdum; presumption Nr. (6), at least in the era of rule of law, is not true; and presumptions $\mathrm{Nr}$. (8) and (11) virtually concern the issues of validity and scope of law, not the interpretation thereof. Cf:: L.M. Du Plessis, A Preliminary Estimation of the Role of the Presumptions of Statutory Interpretation in the New Constitutional Dispensation, "African Law Journal", 1998, Vol. 115, pp. 750-759.

67 Subsection (2) of section 559 of Act IV of 1959 on the Civil Code [of Hungary].

68 In 2009: BH 3, BH 15, BH 33, BH 55, BH 57, BH 58, BH 64, BH 94; in 2011: BH 14, BH 15, BH 18, BH 48, BH 53, BH 58, BH 69, BH 71, BH 97. 
of them once ${ }^{69}$, including the one and only explicitly analogical argumentation in the research sample as well. In the end, as for the interpretation on the basis of other logic formulas, (5/F.) I found none.

Teleological interpretation known generally as interpretation based on the objective purpose or the social function of a given legal norm $(6 .)^{70}$ befell in $17 \mathrm{BHs}(7.83 \%)^{71}$ for solving 22 real hermeneutical dilemmas in the aggregate. This kind of method appears in different phrasings. Accordingly, Hungarian judges refer to this same technique as the aim, goal, purpose, function or role of a given provision, norm or a whole legal institution; the delimitation of the aims etc. thereof; the inner sense of a legal institution; the objective reason for establishing, maintaining or altering a given stipulation or legal norm; the "legal nature' of a provision; the (specific, particular) legal interests needed to be defended by law; and, even several times, simply the 'evidence' or 'obviousity' of any of these aforementioned arguments. As contrasted thereto, historical interpretation (7.), that is, the lawmaker's subjective intent (the legislator's actual, supposed or hypothetical will at the time of drafting the statute at hand $)^{72}$

69 2009-ből: BH 27, BH 57, BH 64, BH 77; 2011-ből: BH 55.

70 The so-called 'purposivists' are those who, according to Scott Fruehwald, "[o]bjectively interpret a statute based on its broad purpose", in addition to (what is, as can soon be seen, scarcely disputable) "relying on heaviliy legislative history". S. Fruehwald, Pragmatic Textualism and the Limits of Statutory Interpretation: Dale v. Boy Scouts of America, "Wake Forest Law Review", Vol. 35, pp. 977.) In other phrasing: "A purposivist judge finds law by measuring a statute's language against the statute's purpose. For the task of discerning purpose, legislative history is a common sense". R. Colinvaux, op. cit., p. 1133. In fact, legislative history is a tool of not an objective but a subjective interpretation. First, a corporate lawmaker cannot "have a unified and discernible intent". M.M. Spence, The Sleeping Giant: Textualism as Power Struggle, "Southern California Law Review", March 1994, Vol. 67, no. 3, pp. 586. Second, "legislative history is often unreliable". S. Fruehwald, op. cit., p. 985. Hence, one cannot become aware of what actually derives from 'legislative history' in a particular case, that is, a judge cannot expect any objective sense from 'legislative history'.

71 In 2009: BH 1, BH 5, BH 21, BH 35, BH 43, BH 57, BH 64, BH 70; in 2011: BH 11, BH 46, BH 62, BH 72, BH 97, BH 104, BH 107, BH 119, BH 121.

72 According to Fruehwald, the so-called 'intentionalists' "try to discern the legislature's specific intent [...] there are two types of intentionalism: archeological intentionalism, which examines the text and legislative history, and hypothetical intentionalism, which asks what the legislature would have said if it had considered the question." S. Fruehwald: op. cit., pp. 976-977. As for the latter, that is, intentionalism, Richard Posner, agreeing therewith, explicitly claimed: "The judge should try to think his way as best he can into the minds of the enacting legislators and imagine how they would have wanted the statute applied to the case at bar." R.A. Posner, Statutory Interpretation - in the Classroom and in the Courtroom, "University of Chicago Law Review", 1983, Vol 50, p. 817. In contrast to him, Cass R. Sunstein strongly criticized this opinion, calling this 'hard originalism' 'an unacceptable project', stating that in case of this kind of (with Posner's words) 'imaginative reconstruction' "we are trying to do something like go back in a time machine and ask the Framers [or, broadly speaking, the legislator - T.J.Z.] very specific 
took place not more than in $8 \mathrm{BHs}(3.69 \%)$, on 9 occasions $^{73}$. Of them, I found reference to regulatory (in Hungary, ministerial) justification (7/A.) in the sample examined in 4 BHs $(1.84 \%)^{74}$; Hungarian judges used arguments based on the so-called legislative history ('travaux préparatoires'), that is, materials of drafting of the legal norm concerned (7/B.) in no cases of my sample; in the end, the Supreme Court denoted the intent of the legislator in general (7/C.) 4 times $^{75}$ $(1.84 \%)$ and the social context of the enactment (or the modification) of the statute $\left(7 / \mathrm{D}\right.$.) only in one case ${ }^{76}(0.46 \%)$. However, it has to be mentioned that the methods of the objective teleological and the subjective historical interpretation often fuse in the practice, since the intent of the lawmaker becomes unambiguously stressed as the goal of the norm frequently just in the text of the law, in addition, the genesis of a law's purpose usually is just the intent of the legislator who wants to give expression to it explicitly ${ }^{77}$. The best example for this kind of fusion of these two techniques is BH 70/2009 in which the Supreme Court referred to both the subjective will of the lawmaker and the objective aim of the legal norm in the course of the same single allusion ${ }^{78}$.

References to concrete works of jurisprudence or legal literature (8.) plays little role in the Hungarian judicature; I found in the sample analysed nothing but one (0.46\%), namely, in BH 74/2009 the High Court of Appeal of Szeged, corroborating the result obtained through other methods, did underpin one of its legal assertions on the ground of a precisely defined jurisprudential work ("Commentary on the Hungarian Criminal Law, p. 688/1. point 6, published by HVG-ORAC"). The interpretation on the basis of constitutional rights, principles, values and constitutional court decisions (9.) is also an extraordinary technique. Albeit the

questions about how we ought to resolve very particular problems". C.R. Sunstein, Five Theses on Originalism, "Harvard Journal of Law and Public Policy", Winter 1996, Vol. 19, no. 2, p. 312.

73 From the year of 2009: in BH 37, BH 64, BH 70; from the year of 2011: in BH 39, BH 54, BH 76, BH 79, BH 104.

74. BH 64/2009, BH 39/2011, BH 76/2011, BH 79/2011.

75 BH 37/2009, BH 64/2009, BH 70/2009, BH 104/2011.

76 BH 54/2011.

77 For the brief criticism of the 'unproductive' opposition of these two methods of interpetation, see e.g.: M. Szabó, Ars iuris: The grounds of legal dogmatics, Bíbor Kiadó, Miskolc 2005, pp. 177-178.

78 It is no accident that plenty of originalist legal scholars and practicing lawyers deem that, in fact, these two processes indeed constitute one single method. For the conception of originalism, see e.g.: S. Fruehwald, op. cit., pp. 976-977; C.R. Sunstein, op. cit., pp. 311-315; L.R. BeVier, The Integrity and Impersonality of Originalism, "Harvard Journal of Law and Public Policy", Winter 1996, Vol. 19, no. 2, pp. 283-291; F. Schauer, Defining Originalism, "Harvard Journal of Law and Public Policy”, Winter 1996, Vol. 19, no. 2, pp. 343-346; P.J. Smith, How Different are Originalism and Non-Originalism, "Hastings Law Journal", 2010-2011, Vol. 62, pp. 707-736; T.B. Colby, P.J. Smith, Living Originalism, “Duke Law Journal”, 2009-2010, Vol. 59, pp. 239-307.) 
constitutional provisions' effect on the legislature is evident, this impact rarely turns up in the judicature in Hungary ${ }^{79}$, indicated by the fact itself that among the analysed 217 cases there were only 5 (2.30\%), with nine different interpretations, where this kind of method occurred ${ }^{80}$. There were a further 11 cases $^{81}$ where the contestants referred to such kinds of grounds but the Supreme Court dismissed all of these ${ }^{82}$.

The interpretation by international treaties, covenants and conventions (10.) is not typical in Hungary, either. In the course of my research, I found 3 such

79 It has to be noted that the regulation on the relationship between the ordinary courts (chiefly, in the hierarchy of them, the Supreme Court /in its present official name: the Curia/) and the Constitutional Court changed after 1 January. Viz., on that day, the new Fundamental (Basic) Law of Hungary (as of 25 April, 2011) by which the former Constitution of the Republic of Hungary (Act XX of 1949 revised and restated by Act XXXI of 1989) was replaced by, came into effect. This new Fundamental Law, that is, Hungary's new constitution, introduced the so-called 'real' constitutional complaint which, since then, has been available in cases of someone challenging the constitutionality of a judicial decision itself or the judicial process. Consequently, after this date, every person has had the right to make a motion to the Constitutional Court if they have thought the ordinary court infringed their fundamentel human rights, hence, the Constitutional Court has been able to directly overview the judicial practice. (Until then the Constitutional Court had only the right to review the constitutionality of statutes applied in particular cases by one or more of the ordinary courts. That was the reason why so few constitution-based interpretations were there in Hungary in the cases that eventuated in 2009 and 2011). (On the new competence of the Constitutional Court of Hungary, see, e.g.: Z.J. Toth, The Protection of (Fundamental) Rights in the Constitution of the Republic of Hungary and the Fundamental Law of Hungary. (Part I and II), "Közjogi Szemle", 2012, no. 3, pp. 11-19, 2012, no. 4, pp. 29-37. As for some particular aspects of this issue, see also: P. Paczolay, Altered stresses in the competences of the Constitutional Court, "Alkotmánybírósági Szemle", 2012, no. 1, pp. 67-69; P. Darák, The constitutional complaint from a judge's point of view, "Alkotmánybírósági Szemle", 2012, no. 1, pp. 70-72; Z. Balogh, I. Marosi, Attractions and repulsions between courts: Thoughts about the constitutional complaint, "Alkotmánybírósági Szemle", 2012, no. 1, pp. 73-79; Gy. Kozma, Connections between the proceedings of the ordinary courts and the Constitutional Court, "Alkotmánybírósági Szemle", 2012, no. 1, pp. 105-108.]; A. Osztovits, On some procedural aspects of the real constitutional complaint, "Alkotmánybírósági Szemle", 2012, no. 1, pp. 109-113; G. Naszladi, The exceptional constitutional complaint, "Jogtudományi Közlöny”, 2012, no. 11, pp. 470-477).

80 Interestingly, among the BHs from 2009, I have found none constitution-based interpretation, whilst in 2009 there were as many as 9, altogether in 5 BHs (namely, in BH 15/2009, BH 32/2009, BH 52/2009, BH 69/2009, BH 118/2009).

81 In 2009: BH 5, BH 21, BH 22, BH 39, BH 48, BH 91; in 2011: BH 17, BH 26, BH 28, BH 69, BH 102, BH 122.

82 These results are in connection with Matyas Bencze's survey, who examined some 2.500 BHs among criminal cases from the years of 1990-2007 and 178 decisions in principle from this same interval in relation to their references to the Constitution, and found less than 100 such BHs and altogether 18 decisions in principle that contained any kind of reference to rights, principles or provisions 'in connection to the Constitution'. Cf:: M. Bencze, Ornament, scrim or supporting pillar? The judicial practice in criminal cases and the Constitution, "Fundamentum", 2007, no. 3, pp. 5-21.) 
kinds of argumentation. In BH 76/2009 the High Court of Appeal of Budapest made its judgement on the grounds of stipulations in the European Agreement relating to Persons Participating in Proceedings of the European Court of Human Rights signed in Strasbourg on March 5, 1996, incorporated into Hungarian law through the promulgation by Act II of 1999. In BH 86/2011 the Supreme Court referred to the European Agreement concerning the Work of Crews of Vehicles engaged in International Road Transport (AETR) promulgated by Act IX of 2001. In the end, in BH 104/2011 it was also the Supreme Court that, explicitly as pure illustration, quoted Articles 7 and 8 of the UN Convention on the Rights of the Child. Besides these, there were further five cases where the possibility of the application of such kind of interpretation emerged ${ }^{83}$, but, in these latter cases, the motions of either of the contestants, therefore, were always dismissed by the Supreme Court. Comparative legal interpretation (11.), not as a definitive one but only as a confirmation of those results deduced by use of other methods, occurred nowhere but in one case (0.46\%), viz., in BH 57/2009 where the $\mathrm{SC}$, in the course of an extraordinary judicial review of a final decision made by the General Court of Budapest in a procedure for annulment of an arbitration award, referred, firstly, generally to the "European practice", then, secondly, it strengthened the soundness of its argumentation by reference to a particular foreign state's precisely defined, particular legal provision (!). This latter, however, was "the point 6 of subsection (2) of section 611 of the Austrian ZPO” [Zivilprozessordnung (Code of Civil Procedure) - T.J.Z.]

Of interpretation by virtue of general principles (12.) I have found none in the sample analysed and substantive interpretation (13.), that is, argumentation on the grounds of some generally established material source of law, e.g. moral principles, justice considerations, policy implications, economic points of view, the interest of the majority etc., occurred very rarely as well, namely, not more than in 2 BHs (0.92\%). Both in BH 5/2009 and BH 78/2011 the Supreme Court made its ruling by implication of, among others, directly the 'public interest' and the 'social interest', however, expressly only in order to corroborate the outcome of the results having been established by other ways of interpretation, and not to decide the case on the interest of people itself. In the end, the Hungarian courts, as could be expected, among the other, law system-specific methods employ only the law of the European Union. In the sample examined I found this kind of argumentation in $5 \mathrm{BHs}(2.30 \%)^{84}$.

83 BH 5/2009, BH 39/2009, BH 91/2009, BH 32/2011, BH 69/2011.

84 Interestingly, all of them eventuated in 2011 (BH 23, BH 51, BH 53, BH 86, BH 120). 


\section{Conclusions}

Summarizing the results of this research, it can be seen that the grammatical interpretation, and, within this one, mainly the legal professional (dogmatic) interpretation has a significant role in the judicial decision-making in Hungary. Allusion to dogmatic meaning of legal texts occurred in two-thirds of the case decisions analysed, whilst interpretation in accordance with ordinary (either semantic or syntactic) meaning of a given word, phrase, sentence or longer text befell in one-third of these cases. The interpretation in accordance with former judge-made law, which emerged more than in one-third of the cases examined, has also an outstanding significance. Among these, the most important is the so-called judicial practice (and, usually conforming to it, particular case decisions), which, if it really exists, every court has to have respect for, almost as if it were even formally obligatory since, albeit there are no cordial cogency for following the directives contained uniformly in all the relevant case decisions, the Supreme Court (in its present name: Curia) informally requires the lower courts to interpret statutory texts by virtue of the 'solid and undiminished' judicial practice, otherwise it annuls those lower court decisions that contradict the understanding of vague legal provisions accepted by the Supreme Court. The third important way of interpretation is the logical one. Though it is true that this method is applied relatively often if a court attempts to reveal the 'real' meaning of an ambiguous legal provision (I have found such a method in every sixth case, in some of them even several distinct ones), its great significance is not gained therefrom but, instead, from the ponderosity and magnitude of this technique, a formal logical argument always belonging to the strong arguments. As compared thereto, most of the other methods are of a slighter but extant importance. This is true for the teleological, historical, contextual (in its narrow sense), ordinary syntactic, constitutional-based and the EU law conforming interpretation. There are other arguments, such as the non-legal professional grammatical, international law-based, non-judicial law enforcement, and the substantive interpretation, which have even less significance in the Hungarian judicial decision-making, having occurred only a few times. Furthermore, comparative legal interpretation befell only in a sole case, and interpretation on the grounds of general principles did not occur at all. 


\section{Bibliography}

- Atiyah P.S., Summers R.S., Form and Substance in Anglo-American Law: A Comparative Study of Legal Reasoning, Legal Theory, and Legal Institutions, Clarendon Press, Oxford 1987.

- Balogh Zs., Marosi I., Vonzások és taszitások biróságok között: Gondolatok az alkotmányjogi panaszról, "Alkotmánybírósági Szemle”, 2012, no. 1.

- Bárdi L., Jogi logika, Eötvös József Könyvkiadó, Budapest 2009.

- BeVier L.R., The Integrity and Impersonality of Originalism, "Harvard Journal of Law and Public Policy", 1996, no. 2.

- Bencze M., Diszitóelem, álcázóháló vagy tartóoszlop? A büntetőbírói gyakorlat és az alkotmány, "Fundamentum", 2007, no. 3.

- Bobek M., Quantity or Quality: Re-Assessing the Role of Supreme Jurisdiction in Central Europe, "EUI Working Paper Law", 2007 no. 36.

- Bohanek O., Comparative legal aspects of the English Common Law system and the Hungarian Roman-German legal regime, with an emphasis in regards to the constitutional differences in criminal justice, "Jogelméleti Szemle", 2010, no. 1.

- Botos V., A birói jogértelmezés útjai a Legfelsőbb Bíróság gyakorlatában, "Jogelméleti Szemle", 2000, nr. 3.

- Bydlinski F., Legal methodology and the concept of law, Springer-Verlag, Wien-New York 1982.

- Colby T.B., Smith P.J., Living Originalism, “Duke Law Journal”, 2009-2010.

- Colinvaux R.: What is Law? A Search for Legal Meaning and Good Judging Under a Textualist Lens, "Indiana Law Journal”, 1997, no. 4.

- Darák P., Az alkotmányjogi panasz bírói szemmel, “Alkotmánybírósági Szemle”, 2012, no. 1.

- Denninger E., Judicial Review Revisited: The German Experience, “Tulane Law Review", 1984-1985.

- Devenish G.E., The Nature of Legal Reasoning Involved in the Interpretation of Statutes. "Stellenbosch Law Review", 1991, no. 2.

- Diederichsen U., The Federal Constitutional Court as the supreme civil court: A study on legal methodology, "Archiv für die civilistische Praxis", 1998.

- Du Plessis L.M., A Preliminary Estimation of the Role of the Presumptions of Statutory Interpretation in the New Constitutional Dispensation, "African Law Journal", 1998.

- Eskridge W.N., The New Textualism, "UCLA Law Review”, 1989-1990.

- Fikentscher W.: Methoden des Rechts, J.C.B. Mohr, Tübingen 1975-1977.

- Fruehwald S., Pragmatic Textualism and the Limits of Statutory Interpretation: Dale v. Boy Scouts of America, "Wake Forest Law Review", 2000.

- Garlicki L., Constitutional courts versus supreme courts. "I•CON”, 2007, no. 1.

- Gebauer M., Uniform Law, General Principles and Autonomous Interpretation, "Uniform Law Review", 2000, no. 4.

- Greene A.S., The Missing Step of Textualism, "Fordham Law Review", 2005-2006.

- Hart H.L.A., The Concept of Law, Clarendon Press, Oxford 1997.

- Heck P., Gesetzauslegung und Interessenjurisprudenz, Verlag von Mohr, Tübingen 1914. 
- Hoecke M.V., Ost F., Legal Doctrine in Crisis: Towards a European Legal Science, "Legal Studies", 1998, no. 2.

- Holländer P, The Role of the Constitutional Court for the Application of the Constitution in Case Decisions of Ordinary Courts, "Archiv für Rechts- und Sozialphilosophie", 2000, no. 4.

- Jakab A., Judicial Reasoning in Constitutional Courts: A European Perspective, "German Law Journal", 2013, no. 8.

- Jhering R. v., Der Zweck im Recht, Erster Band, Druck und Verlag von Breitkopf \& Härtel, Leipzig 1877.

- Keszthelyi B., A büntető jogegységi határozatok elemzése, “Jogelméleti Szemle”, 2000, no. 3 .

- Kozma Gy., Kapcsolódások az Alkotmánybiróság és a rendes biróságok eljárásai között, "Alkotmánybírósági Szemle", 2012, no. 1.

- Kuhn Z., Making Constitutionalism Horizontal: Three Different Central European Strategies, [in:] The Constitution In Private Relations: Expanding Constitutionalism, eds. A. Sajó, R. Uitz, Eleven International Utrecht 2005.

- Leff A.A., The Leff Dictionary of Law: A Fragment, "Yale Law Journal”, 1984-1985.

- Lopez E.G., Judicial Review in Spain: The Constitutional Court, "Loyola of Los Angeles Law Review", 2008.

- Luhmann N., Legal Argumentation: An Analysis of its Form, "The Modern Law Review", 1995, no. 3 .

- MacCormick N.D., Argumentation and Interpretation in Law, "Argumentation”, 1995, no. 3 .

- MacCormick N.D., Summers, R.S., Interpreting statutes: a comparative study, Dartmouth Publishing Company, Aldershot 1991.

- Makai A., Parádi Á., Büntető jogértelmezés Magyarországon a '90-es években, "Jogelméleti Szemle", 2000, no. 3.

- Manzin M., A rhetorical approach to legal reasoning: The Italian experience of CER$M E G$, [in:] Exploring Argumentative Contexts, eds. H. v. E. Frans, G. Bart, John Benjamins Publishing Company, Amsterdam 2012.

- Naszladi G., Az alkotmányjogi panasz kivételes esete, “Jogtudományi Közlöny”, 2012, no. 11.

- Nelson C., What is Textualism?, "Virginia Law Review”, 2005.

- Osztovits A., A valódi alkotmányjogi panasz egyes eljárásjogi kérdéseiről, "Alkotmánybírósági Szemle", 2012, no. 1.

- Paczolay P., Megváltozott hangsúlyok az Alkotmánybíróság hatásköreiben, "Alkotmánybírósági Szemle”, 2012, no. 1.

- Perelman Ch., The Idea of Justice and the Problem of Argument, Routledge \& Kegan Paul, London 1963.

- Perelman Ch., The Realm of Rhetoric, University of Notre Dame Press, Notre Dame 1982.

- Pohlmüllner T., Közigazgatási határozatok 1997-99, “Jogelméleti Szemle”, 2000, no. 3.

- Pokol B., A jogértelmezés alapjai, “Magyar Jog”, 1999, no. 11.

- Pokol B., A felsőbírósági jogértelmezés Magyarországon, "Jogtudományi Közlöny”, 1999, no. 11. 
- Posner R.A., Statutory Interpretation - in the Classroom and in the Courtroom, "University of Chicago Law Review", 1983.

- Redish M.H., Interpretivism and the Judicial Role in a Constitutional Democracy: Seeking an Alternative to Originalism, "Harvard Journal of Law and Public Policy", 1996, no. 2.

- Saunders K.W., Informal Fallacies in Legal Argumentation, "South California Law Review", 1992-1993.

- Savigny F.C. v., System des heutigen Römischen Rechts. Erster Band, Berlin 1840.

- Scalia A., A Matter of Interpretation: Federal Courts and the Law, Princeton University Press, Princeton 1997.

- Scallen E.A., Classical Rhetoric, Practical Reasoning, and the Law of Evidence, "American University Law Review", 1995, no. 5.

- Schauer F., Defining Originalism, "Harvard Journal of Law and Public Policy", 1996, no. 2.

- Sherry S., Textualism and Judgement, "The George Washington Law Review”, 1998, no. $5 / 6$.

- Smith P.J., How Different are Originalism and Non-Originalism, "Hastings Law Journal", 2010-2011.

- Smith P.J., Textualism and Jurisdiction, "Columbia Law Review”, 2008.

- Spence M.M., The Sleeping Giant: Textualism as Power Struggle, "Southern California Law Review", 1994, no. 3.

- Stone S.A., Governing with Judges: Constitutional Politics in Europe, Oxford University Press, Oxford 2000.

- Strauss D.A., The New Textualism in Constitutional Law, "The George Washington Law Review", 1998, no. 5/6.

- Sunstein C.R., Five Theses on Originalism, "Harvard Journal of Law and Public Policy", 1996, no. 2.

- Szabó I., A jogszabályok értelmezése, KJK, Budapest 1960.

- Szabó M., Ars iuris: A jogdogmatika alapjai, Bíbor Kiadó, Miskolc 2005.

- Toth J.Z., Az egyéni (alap)jogvédelem az Alkotmányban és az Alaptörvényben (I-II. rész), "Közjogi Szemle", 2012, no. 3 and 4.

- Turano L., Quis Custodiet Ipsos Custodes?: The struggle for jurisdiction between the Tribunal Constitucional and the Tribunal Supremo, "International Journal of Constitutional Law", 2006, no. 4.

- Windscheid B., Lehrbuch des Pandektenrechts. Erster Band. Verlagshandlung von Julius Buddeus, Düsseldorf 1873.

- Wróblewski J., Legal reasonings in legal interpretation, "Logique et Analyse", 1969.

- Wróblewski J., Legal Syllogism and Rationality of Judicial Decision, "Rechtstheorie”, 1974, no. 1. 
Summary: The present paper deals with the methods of statutory interpretation, focusing, primarily, on the Hungarian practice thereof. It uses the term 'interpretation' in the sense of Jerzy Wróblewski's well-known category as an activity that one does if the meaning of a given text is vague or dubious and he/she wishes to reveal the appropriate meaning of the text in question. Firstly, the paper reviews the techniques by use of which judges (or anybody else) can decide what a given word, phrase, sentence or text means, or what it does not, establishing a classification that attempts to cover the pool of the possible methods of statutory interpretation. Secondly, the article analyses and introduces, in a legal sociological way, what kind of methods and in what proportion are applied by high courts in Hungary, and, mainly, by the Supreme Court of Hungary in the judicial practice.

Keywords: statutory law, Supreme Court

\section{Metody interpretacji ustaw w praktyce Sądu Najwyższego na Węgrzech}

Streszczenie: Artykuł naukowy traktuje o wykładni prawa dla Sądu Najwyższego na Węgrzech. Autor dokonuje analizy oraz interpretacji charakterystycznej dla Sądu Najwyższego na Węgrzech oraz poszczególnych procesów i zjawisk związanych z wykładnią prawa. Artykuł jest również filozoficznym rozważaniem nad tym, czym jest prawo i czym jest wykładnia prawa, w ujęciu realistycznym i pragmatycznym.

Słowa kluczowe: wykładnia prawa, Sąd Najwyższy 